\title{
Increasing Capability of Local Government Internal Auditors in Detecting Fraud Through Strengthening Professional Commitments and Organizational Commitments
}

\author{
Mochammad Solichin ${ }^{1}$ \\ \{massolichin72@gmail.com\} \\ University of Technology Yogyakarta, Jalan Ring Road Utara No.81, Mlati Krajan, 55285 \\ Sleman, Daerah Istimewa Yogyakarta, Indonesia ${ }^{1}$
}

\begin{abstract}
Various efforts have been made by the government in eradicating and preventing corruption. However, it does not significantly reduce the number of corruption cases every year. Reforms in regional financial management were found to be unable to increase accountability in regional financial management. In the midst of the strong demands of accountability from the community, there are still many cases of fraud in financial management. In this case, a problem arises as to why the internal auditor, in this case, the regional inspectorate as an internal supervisor can miss fraud cases and all forms of irregularities in the financial management of the area. Fraud cases that the auditor cannot detect cause a perception of the auditor's ability to detect fraud. Various improvements have been made and continue to be carried out to improve the auditor's ability, but the focus point has not been known so that it cannot provide satisfactory results. This paper tries to offer a research-based approach to individual factors in this case professionalism commitment and organizational commitment, to determine its influence on the internal capacity of local government auditors in detecting fraud. The aim is to get a clear and comprehensive picture so that it can make a positive contribution to improving the role of internal auditors in local government in detecting fraud in the future.
\end{abstract}

Keywords: professionalism commitment, organizational commitment, detecting fraud, internal auditors, local government

\section{Introduction}

The implementation of regional autonomy now requires local governments to conduct financial management that is clean, fair, transparent and accountable to create good governance. One element in financial management is an internal monitoring function carried out by the Government's Internal Supervisory Apparatus (called APIP). APIP consists of the Financial and Development Supervisory Agency (called BPKP), the inspector general, and the regional inspectorate. According to the Government Regulation of the Republic of Indonesia No. 41 of 2007 and Regulation of the Minister of Home Affairs of the Republic of Indonesia No. 64 of 2007, elements of regional supervision were the regional oversight body consisting of the provincial inspectorate, the district inspectorate, and the city inspectorate. Inspectorates are organizations that have an internal audit function. Organizations that have an internal audit function will be better able to detect and reduce the possibility of fraud (Coram, et al. 2006 and Hogan, et al. 2008).

The Regional Inspectorate is a functional supervisory device that is under and responsible to the regional head and administratively receives guidance from the Regional Secretary. The role of the regional inspectorate has now shifted, one of which is related to an audit by the regional inspectorate as of the internal auditor of the local government who conducts internal audits. As stated in the Government Regulation of the Republic of Indonesia Number 60 of 2008 article 50 paragraph (1), it is explained that the inspections carried out by the inspectorate consist of performance checks and examinations with the specific purpose of several or all programs or activities funded by the regional budget (called APBD) so that it produces advice or input for improvement and progress in the administration of government affairs in the region.

The regional inspectorate is an internal auditor who is an institution that has the authority to oversee the running of government in the region. The Inspectorate is also the spearhead in increasing 
accountability and transparency in financial management in the region. Accountability can be realized through internal audits (Togiman 2000 and Sawyer et al. 2006). In the Minister of Home Affairs Regulation Number 64 of 2007 it is stated that in carrying out the task of supervising government affairs, the Inspectorate has the following functions: first, planning a monitoring program; second, formulating supervisory policies and facilities; and third, inspection, investigation, testing and assessment of supervisory duties. To support the implementation of the tasks of the Regional Inspectorate in carrying out its oversight function so that it can run optimally, more intensive performance is needed from the Regional Inspectorate to optimize the tasks and responsibilities it carries out. As an internal control institution, before irregularities occur, the Inspectorate should be able to detect it quickly, and management can respond or follow up on the existence of these weaknesses correctly (Russell and Regel 1996) so that weaknesses can be corrected and not repeated again.

Until now, corruption is still a serious problem that must be faced by the Government of Indonesia. The impact of widespread corruption is very detrimental to state finances. Corruption can also hamper national development which results in damaging the social and economic rights of the wider community. Fraud in government agencies does not only involve people who have high positions but can also involve people who are under it. This fraud can occur in both the central government and regional governments. Forms of fraud that are often carried out include manipulating financial statements, removing transaction documents, shopping mark-ups, and misappropriation of revenue realization that can harm the State / regional finances. These actions are carried out with motives for both personal and group interests. This is reinforced by data in 2017 from a survey conducted by a corruption observer, Transparency International, that Indonesia was ranked 96th out of 180 countries surveyed. Among ASEAN countries, Indonesia is still ranked 5th under Singapore, Brunei, Malaysia, and Timor Leste. Until 2016, out of 541 regional heads in Indonesia, there were 360 regional heads trapped in corruption cases (Tjandra, 2017). This figure is a legal case that befell the head of the region, has not shown the number of corruption cases at the level of officials and local government employees. Cases of fraud occurred even though the regional government had a system of internal government supervision in the form of regional inspectorates. This internal supervision system complements the external supervision carried out by the Supreme Audit Agency and supervision by the public. However, it turned out that this internal supervision system proved to be ineffective in preventing corruption in the region. Rahardjo (2017) said that corruption cases that occurred in the regions did not appear to be based on the Inspectorate's report. The handling of corruption cases actually originated from public reports.

One of the responsibilities of internal auditors is to detect misstatements caused by errors or fraud. According to Lisa and Barry (1997), the function of internal auditors is to assist management in preventing, detecting and investing fraud. However, so far the position of regional inspectorates has been weak and has become the legitimacy of regional heads for their work (Suhartanto, 2014). The occurrence of cases of irregularities and fraud in regional financial management shows the weak role and performance of the internal auditors of the local government. Even though the relationship between the role of the Regional Inspectorate as an internal auditor and prevention of fraud is very strong (Taufik, 2011). According to Rozmitha and Apandi, (2012) internal government auditors play a role in detecting fraud. The internal auditor's failure to detect fraud caused a loss of public confidence in the internal auditor.

In the current era of bureaucratic reform, organizations in regional governments face many challenges in terms of human resource management. Organizations are faced with conditions relating to the low professional level of employees and high dissatisfaction which is almost certainly both will be antecedent variables of the low work performance of employees in carrying out their duties. Therefore, effective handling is needed so that the existing human resources can be professional so that they contribute positively to the formation of the image of the organization (Martak, 2015). Professional attitudes and actions are demands in various fields of profession, including the profession as an internal auditor. An auditor is said to be a professional if in carrying out an examination, he produces an audit that meets the stipulated provisions and in accordance with the code of ethics or professional standards. Professionalism is a work attitude. Low employee attitudes can be seen from the employees' indifference to their work. Work is done carelessly, there is no effort to improve the way of working and not respecting the results of his own work. The professionalism of accountants includes the standards of 
professionalism, knowledge, and skills, human relations and communication, continuing education, and professional accuracy (Sawyer, 2006).

The study of the level of professionalism of the profession of auditors has not been done much by academics. However, it is fully realized that professionalism is a must so that the profession will survive in the future. Professionalism of a professional will become increasingly important if the professionalism is related to the work of the individual, so that in the end it can contribute work to companies or professional organizations where they work. For companies or organizations, if empirically there is a relationship between the level of professionalism of individuals and the results of individual work, then this will be a value for the company in maintaining personal professionalism. Aranya (1981) in his study emphasized that professional commitment shows a situation where an employee has the same values and goals as the work or profession that is being undertaken, is involved in achieving professional goals and intends to maintain membership in professional associations.

The professionalism of an auditor is needed to examine what information is needed in making a quality audit assessment. Auditors will always be required for professionals to do every profession. Professionalism can also be reflected in the internal auditor's compliance with the applicable professional code of ethics. The code of ethics sets standards of behavior as guidelines for all internal auditors. The principles of professional behavior provide guidance for members in carrying out their professional responsibilities and express the basic principles of ethics and professional behavior. These principles require a strong commitment to respectable behavior despite sacrificing personal gain.

\section{Literature Review}

Professionalism is associated with the view that work shows a number of characteristics required by the profession (Goode, 1957; Kalbers and Fogarty, 1995). This traditional analysis is often criticized by scholars today who oppose the effectiveness of a number of characteristics, question the generality of models taken from one or two cases of history (eg law and medicine) and systematically underestimate the role of power and social conflict (Kalbers and Fogarty 1995). An alternative view of the emergence and success of professionalism is based on the maximum sociology of Weber and Karl Marx. For this purpose, the goal of professionalism for accountants can be considered as an alternative to motivated personal market control or as a means of maintaining a capitalist socialist structure (Roslender, 1990).

An alternative view of the profession failed to develop any systematic empirical evidence. In addition, the inconsistency of expectations for individual-level analysts has been developed by Roslender (1990) who studied the role of accountants in this perspective. The results concluded that most practitioners lacked political awareness and the distributional implications of the accounting profession. Because professionalism as an important individual attribute is difficult to implement outside the conventional functionalist tradition. The researchers use many concepts of professionalism as developed by Hall (1968) to measure the professionalism of the profession of auditors as reflected in attitudes and behavior. There is a reciprocal relationship between attitude and behavior, namely the behavior of professionalism is a reflection of the professionalism and vice versa.

Research on the influence of professionalism on performance has been carried out in Indonesia. However, research that focuses on examining the effect of professionalism on the auditor's ability to detect fraud has not been done much. The use of professionalism in carrying out its duties is a minimum requirement that must be owned by the auditor so that the tasks carried out are in accordance with the rules of the profession. Research carried out by Surnardi (2002), Tirta and Sholihin (2004), Ardini and Sawaljuwono (2005), Lastanti (2005) and Koroy (2008) use the object of research by government external auditors. While Alim's research, et al. (2007) use independent auditors who work in the Public Accounting Firm (KAP). For this reason, it is necessary to conduct research by using a sample of internal auditors to determine their influence on their ability to detect fraud for internal auditors of the local government.

Internal auditors in local governments have been given an important role and better regulatory support. The internal auditor's role in the region which was originally only repressive has developed into preventive action. In addition, the regional inspectorate was also given a role as a consultant, so that Regional Organization Organizations (called OPD) in their regions could consult on the use of regional budgets so as not to cause practices of lawlessness. However, increasing roles and arrangements in practice does not significantly reduce the level of corruption in the region (Katharina, 2017). There are 
still regions that have obtained reasonable audit results (accepting unqualified opinions) in the financial statements, but their regional heads are involved in corruption cases. This shows that regional internal auditors have not been able to secure state assets from corruption. If the internal auditors of the local government have the ability to detect fraud, then the occurrences of fraud in financial implementation in the local government can be avoided.

The important role of the internal auditor in detecting fraud will only be a slogan if the leadership of the organization in the local government does not provide support in the form of commitments and actions that encourage the functioning of the internal auditor's role. Aranya, et. al (1982) in his study analyzed the effect of organizational commitment and professionalism on the job satisfaction of accountants. By using organizational commitment and professional commitment as predictors of job satisfaction, this study found a statistically significant correlation between organizational commitment and auditor performance.

In addition to professionalism, organizational commitment is one of the individual factors that influence performance improvement. Organizational commitment can be created if members of the organization are aware of their rights and obligations as members without seeing their position or individual position. According to Bariyima (2012), the success and performance of a person in a field of work are largely determined by how much organizational commitment he has. High organizational commitment will increase high performance too.

Commitment is defined as the power of identifying individuals who are in an organization (Curtis et al., 2001). Commitment can be said as the identity and need for service in a job that has high responsibility (Osinsky and Mueller, 2004). A person who has a commitment to his organization is a person who has loyalty and a sense of pride with his organization so he has the desire to work and complete his tasks well (Ghorbanpour et al., 2014). The existence of organizational commitment owned by an employee will have a positive influence on the organization because employees with high organizational commitment will have a sense of belonging to the organization (Putri, 2015). Meyer et al. (1989) and Fernando et al. (2005) suggested that organizational commitment has a positive relationship with performance.

Organizational commitment can be built on the basis of job trust in organizational values, the willingness of members of the organization to help realize organizational goals and high loyalty to remain a member of the organization. A good relationship will be established if the auditor has a high sense of loyalty and can identify himself with the place he works. The existence of organizational commitment owned by the auditor will have an impact on auditor performance. Siders et al. (2001) state that commitment affects performance.

\section{Conclusion}

Many factors are the drivers of corrupt behavior that occurs in local governments. One important factor that needs to be considered is the lack of supervision by internal auditors. Therefore, the role of the inspectorate must be increased as an effort to prevent irregularities in financial management in the local government. Internal auditor's weaknesses in preventing corruption, especially in terms of its role in detecting fraud in local governments, need to be studied more deeply, especially related to the factors that influence it. This needs to be done so that it can be used as a material consideration for policymakers to be used as a basis for decision-making related to efforts to increase the internal auditor's ability to local governments in detecting fraud.

Auditors with high professional attitudes will have an influence on their performance so that the auditor can work better and be able to provide audit results that can be trusted by interested parties both internal and external parties of the company (Halim, 2008). The results of research conducted on external auditors state that auditors who behave professionally are more trusted as auditors who have good competence so that the results of the audits will be better. The higher the professionalism of an auditor, the better the performance of the auditor (Prabhawa et al., 2014).

Employees who have a high commitment to the organization will show a positive attitude and will try to make a positive contribution to the organization so that organizational goals can be achieved. An auditor who has a high organizational commitment will work well and provide the best for his organization and there will be a sense of ownership of the organization so that the commitment that is owned will result in increased auditor performance (Prabayanthi, 2018). 
This research will contribute to efforts in combating corruption in the implementation of governance in the regions related to the internal role of regional government auditors. The results of this study can be used as consideration in an effort to improve the internal capabilities of auditors in detecting fraud while they carry out their duties in internal supervision.

\section{References}

[1]Alim, N., et al.: The effect of competence and independence on audit quality with auditor ethics as a moderation variable. National Symposium on Accounting X; AVEP 08, pp. 1-26. (2007)

[2]Aranya, N., J. Pollaock, \& J. Amernic.: An examination of professional commitmen in public accounting. Accounting, Organization and Society 6, pp.271 - 282. (1981)

[3]Aranya, R. L., \& J. Armenic.: Accounting job satisfaction: a path analysis. Accounting, Organization and Society 7 (3), pp. $201-215$. (1982)

[4]Meyer, J. P. et al.: Organizational commitment and job performance: it's the nature of the commitment that counts. Journal of Applied Psychology, 74: pp:152-156. (1989)

[5]Fernando, J., Mulki, J.P., \& Marshall, G.W.: A meta-analysis of the relationship between organizational commitment and salesperson job performance. Journal of Business Research, 58: pp:705714. (2005)

[6]Ardini, L \& Tjiptohadi, S.: Auditor's competence in his experience disclosing fraud. Vol.5, No.1, pp. 101-142. The Journal of Accounting, Management, and Economics Research.. (2005)

[7]Bariyima, D. K.: Auditor internaling and performance of government enterprises: a nigeria study. Double Blind Peer Reviewed International Research Journal, 12 (6): pp.1-17. (2012)

[8]Mulford, C. W., \& Eugene E. C.: The financial number game. Translator Prasojo, Jakarta: PPM Management Publisher. (2010)

[9]Finegan, J.: The impact of personal values on judgments of ethical behavior in the workplace. Journal of Business Ethics, Sep, 13, 9. (1994)

[10]Coram, P., C. Ferguson \& R. Moroney.: The value of internal audit in fraud detection. Department of Accounting and Business Information System, Pg. 4. The University of Melbourne. (2006)

[11]Curtis, S, \& Dennis W.: Retaining employess - the fast track to commitment. Vol. 24 Iss: 8/9, pp. 5964 Management Research New.. 2001)

[12]Elias. R.Z.: The impact of professional commitment and anticipatory socialization on accounting students ethical orientation. Journal of Business Ethics. pp. 83-90. (2006)

[13]Ghorbanpour, Z.: Investigating the effect of organization commitment on performance of auditors in the community of certified accountants. Jurnal of Contemporary Research in Business. Islamic Azad University. (2014)

[14]Goode, W.: Community within a community : the profession. American Sociological Review 22 : pp.194-200. (1957)

[15]Hall, R.: Profesionalization and bureaucratation. American Sociological Review 33 : pp.92 - 104. (1968)

[16]Hogan, C.E., Z. Rezaee, R.A. Riley \& U. Velury.: Financial statement fraud: insights from the academic literature. Vol. 27, No. 2, pp. 231-252. Auditing: A Journal of Practice \& Theory. (2008)

[17]Kalbers L.P. \& Fogarty.: Professionalism and its consequences: a study internal's auditor. A journal Practice and Theory (Spring) : pp. 64 -85. (1995)

[18]Katharina, R.: Strengthening the role of regional inspectorates in eradicating corruption. Brief Information on Domestic Government, Vol. IX, No. 18 / II / Puslit / September / 2017. (2017)

[19]Koroy, T. R.: Fraud detection (fraud) of financial statements by external auditors. Vol. 10, No.1, pp. 2233. Journal of Accounting and Finance. (2008)

[20]Lastanti, H.S.: Overview of competence and independence of public accountants: reflections on financial scandals. Vol. 5, No.1, pp. 85-97. Media Research Accounting, Auditing and Information. (2005)

[21]Lisa M.P., \& J.B. Barry.: Heightened responsibilities of the auditor internal in the detection of fraud. Vol. 23, No. 12, pg 38. Managerial Finance. (1997) 
[22]Martak, M. N. M.: Analysis of the effect of professionalism and organizational commitment on job performance through job satisfaction at the auditor of the public accounting firm in Surabaya. Journal of Economics and Business. Year XXV, April 1, pp. 65-80. (2015)

[23] Osinsky, P. \& W. Mueller, C.: Professional commitment of Russian provincial specialist. Journal of Work and Occupations. PP. 193-224. (2004)

[24]Peraturan Pemerintah Republik Indonesia No. 41 Tahun 2007, Tentang Organisasi Perangkat Daerah.

[25]Peraturan Menteri Dalam Negeri Republik Indonesia No. 64 Tahun 2007, Tentang Pedoman Teknis Organisasi dan Tata Kerja Inspektorat Provinsi dan Kabupaten/Kota.

[26]Peraturan Pemerintah Republik Indonesia Nomor 60 Tahun 2008 Tentang Sistem Pengendalian Intern Pemerintah.

[27] Prabayanthi, P. A. \& Ni L. S. W.: Effect of professionalism, organizational culture and organizational commitment on auditor performance. Vol.22.2. February (2018): pp. 1059-1084. Accounting E-Journal of Udayana University. (2018)

[28]Prabhawa, K. A.: Influence of supervision, regionalism, and communication in teams on the performance of auditors of bpkp representatives in bali province. E-Journal of Accounting. University of Education Ganesha Undergraduate Accounting Department. (2014)

[29]Putri, K. K. M. D. \& I.D.G Dharma Suputra.: The effect of independence, professionalism and professional ethics on auditor performance at the public accounting firm in Bali. E-Journal of Accounting. Udayana University. (2013)

[30]Rahardjo, A.: The role of the inspectorate to prevent corruption. Retrieved from http://www.lampost.co/berita-peran-inspektorat-mencegah-korupsi-Aug 28th 2017. (2017)

[31]Roscoe.: Research methods for business, New York. Mc Graw Hill. (1982)

[32]Roslender, R.: The prospects for satisfactorily measuring and reporting intangibles: time to embrace a new model of accounting?, Vol. 13 Issue: 4, pp.338-359. Journal of Human Resource Costing \& Accounting. (2009)

[33]Rozmita, D. Y. R. \& R. Nelly N. A.: fraud symptoms and the role of internal auditors in detecting fraud in higher education (qualitative study), Proceedings of the 15th National Accounting Symposium Banjarmasin. (2012)

[34]Russell, J.P. \& T. Regel.: After the quality audit: closing the loop on the audit process. Vol. 29, pp.65. American Society for Quality. (1996)

[35]Sawyer, B. L., Dittenhofer, M. \& Scheiner, J.,. Sawyer's internal audit. Cetakan ke-3. Penerjemah: Ali Akbar. Penerbit Salemba Empat. Jakarta. (2006)

[36]Siders, Scott., et Al.: The effects of privileging moral or performance character development in urban adolescents. The Journal Of Early Adolescence, pp. 1-44. (2001)

[37]Suhartanto.: APIP strategy in prevention of corruption crime. Downloaded November 4, 2018. http://www.pusdiklatwas.bpkp.go.id. (2014)

[38]Surnardi \& Pancawati H.: The effect of imaging on professionalism and the effect of professionalism on job performance and satisfaction: case study of BPKP auditors. Vol. 9, No.1, pp. 1-25. Journal of Business and Economics. (2002)

[39]Tjandra, W. R.: Investigating corruption roots in the region. Downloaded November 2018. Retrieved from https://nasional.kompas.com/. (2017)

[40]Taufik, T.. Effects of the role of the regional inspectorate on prevention of fraud (studies in provinces and districts / cities in Riau). Vol. 3, No.2, pp. 512-520. Pekbis Journal. (2011)

[41]Tirta, R., \& Sholihin, M.: The effects of experience and task spesific knowledge on auditors' performance in assessing a fraud case. Vol 8, No. 1. Journal of Accounting and Indonesian Auditing. (2004)

[42]Togiman, H.: Effect of internal auditor roles and supporting factors on efforts to improve internal control and company performance. Thesis is not published. UNPAD. Bandung. (2000) 